Pamela Higgins

\title{
A luxury of libraries \\ Baltimore libraries and special collections
}

B altimore's rich history provides a perfect backdrop for the development of the city's remarkably diverse libraries, from the Enoch Pratt Free Library-one of the oldest public libraries in the country-to the more than 20 college and university libraries in the Baltimore area. Special libraries abound as well, with intriguing collections as eclectic as the city itself.

The Baltimore library community welcomes ACRL National Conference attendees to visit the libraries highlighted in this brief introduction, which includes the large and the small, and some of the hidden treasures that will be a delight to discover. Web addresses have been included for hours and directions. Baltimore is an easy town to get around; cabs are plentiful and generally your best bet for transportation.

\section{Mt. Vernon cultural district}

Just three miles from the Inner Harbor, the Mount Vernon Cultural District is Baltimore's cultural and arts center. Mount Vernon preserves and celebrates the breadth of Baltimore's 19th- and 20th-century brilliance with its extraordinary collection of historical and cultural institutions, including five libraries.
George Peabody Library (17 East Mt. Vernon Place, www.georgepeabodylibrary. jhu.edu). The library dates from the founding of the Peabody Institute in 1857, which philanthropist George Peabody established as a cultural center for the city's residents. The institute originally comprised the nation's first music academy, an art gallery, a lecture series, and a library, envisioned by Peabody as one which "should consist of the best works on every subject..." The 300,000 volume Victorian research collection includes books dating from the 15th century, with particular strength in the 19th century. Woodrow Wilson, John Dos Passos, and $\mathrm{H}$. L. Mencken are among the luminaries who have conducted research there. An alcove on the main floor is devoted to a recent gift of H. L. Mencken materials.

The library's magnificent interior features an atrium surrounded by five tiers of ornamental cast-iron balconies and gold-scalloped

Pamela Higgins is special assistant to the director for external relations at Johns Hopkins University's Sheridan Libraries, e-mail: pamela.higgins@jhu.edu

(C) 2006 Pamela Higgins 
columns rising more than 60 feet to a latticed skylight.

An exhibition gallery is located in the former reading room. The 150th anniversary of the founding of the institute will be the subject of the spring 2007 exhibition.

The Arthur Friedheim Library, The Peabody Institute (1 East Mt. Vernon Place, www.peabody.jhu.edu/library). Adjoining the Peabody Library is the music conservatory, one of the nation's major sources of professionally trained musicians, and a division of Johns Hopkins since 1977. Established when the institute opened in 1866, the music library includes more than 100,000 books, scores, and sound recordings. Highlights of its special collections include a signed Beethoven canon and many rare 18th- and 19th-century scores.

The Peabody Archives are also located here and chronicle not only the Peabody's institutional history, but also the cultural development of Baltimore and Maryland from the mid-19th century to the present. The records of many performing arts institutions in the Baltimore area, including the Baltimore Symphony Orchestra and the Lyric Opera House, are also maintained by the archives.

Sculptures, paintings, and other works from more than 1,400 objects in the original art collection are displayed throughout the archives and the institute, on loan from the state of Maryland which acquired the collection in 1996.

Enoch Pratt Free Library (400 Cathedral Street, www.epfl.net). George Peabody's generosity inspired others, and philanthropist Enoch Pratt's gift to the city in 1882 created one of the first urban public library systems in the country. The original Central Library opened in 1886 on Mulberry Street, along with four neighborhood branches. The current Central Library building on Cathedral Street opened in 1933 and the Italian Renaissance structure features a street-level entrance flanked with large department-store style windows.

The Pratt Library has served as the State Library Resource Center since 1971 and enjoys

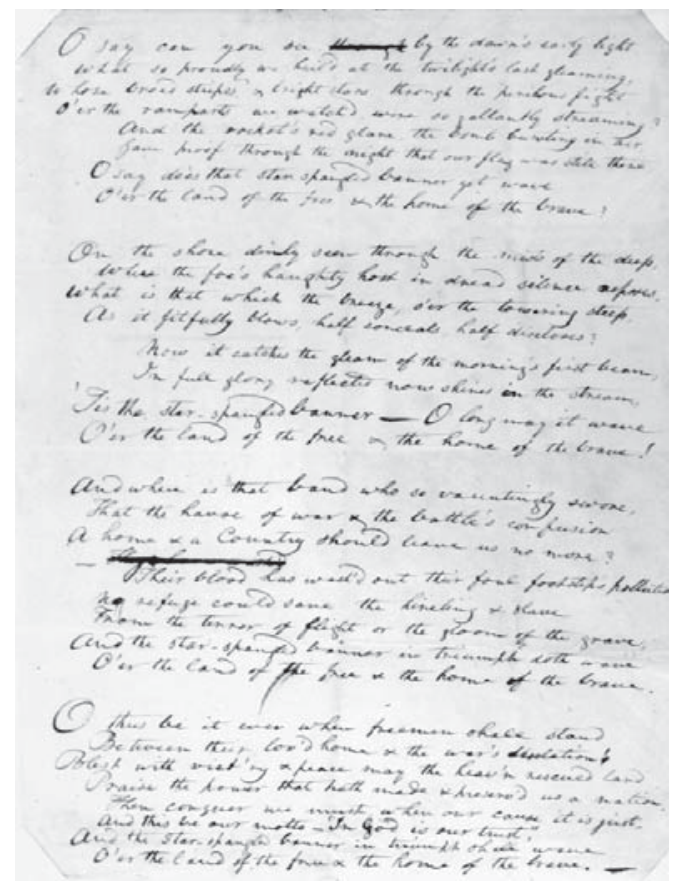

The Star-Spangled Banner, 14 September 1814. Courtesy Maryland Historical Society.

a national reputation as an innovative public library system. Highlights of the 2 million-volume collection include the African American department, which contains comprehensive historical and contemporary materials relating to African Americans in Maryland and around the world, and the H. L. Mencken and Edgar Allan Poe collections.

The Maryland Historical Society, H. Furlong Baldwin Library (201 W. Monument Street, www.mdhs.org). Maryland's oldest cultural institution maintains a library of more than 7 million items, including books, extensive genealogy indexes, photographs, manuscripts, prints, and ephemera reflecting the history of Maryland and its people. Highlights include Francis Scott Key's original manuscript of The Star-Spangled Banner, papers of Maryland's colonial governors and signers of the Declaration of Independence, and more than 700,000 photographs that bring four centuries of Maryland history to life.

Items from the library's expansive collections are displayed in the Hackerman Gallery and the Mary Washington Marr Newhall Gallery. The Historical Society also features a used-book store, proceeds of which benefit the library. 
Walters Art Museum Library (600 North Charles Street, www.thewalters.org). The library supporting the internationally renowned Walters Art Museum was established by the original curator of manuscripts and rare books. Reflecting the museum's distinguished collection of world art from antiquity to the 21st century, the library's extensive art history collection includes more than 50,000 monographs, 250 journals, and 25,000 auction catalogs. Collection strengths include ancient art, Asian art, Renaissance and Baroque art, 18th- and 19th-century European and American art, illuminated manuscripts and rare books, Islamic art, and medieval art. By appointment, (410) 547-9000 x297.

Just a few blocks from the Mt. Vernon Cultural District is the northern arts district, which includes the Meyerhoff Symphony Hall, Lyric Opera House, and the library of one of the nation's top art schools.

Maryland Institute College of Art, Decker Library (1401 Mount Royal Avenue, www.mica.edu/library/). Founded as the Maryland Institute for the Promotion of Mechanical Arts in 1826, the institute established a library for its "members, their sons and apprentices." In 1848, a School of Design and a School of Fine Arts were added to the original program. Today the institute's undergraduate and graduate programs are ranked among the nation's top programs in visual arts and design. The Decker Library houses a collection of 55,000 books, over half of which cover the visual arts. Included are a growing collection of artists' books, used to support courses on that subject and in printmaking and photography. Other collection strengths include painting, drawing, sculpture, printmaking, graphic design, photography, and illustration.

There are three major exhibition galleries on the campus, and numerous smaller galleries and informal exhibition spaces across the campus, all of which are free and open to the public. Visit www.mica.edu for more detailed information.

Baltimore Museum of Art , E. Kirkbride Miller Art Library (10 Art Museum Drive, www.artbma.org/education/library.html). The art library has been an integral part of the museum since its founding in 1929. The collection of more than 50,000 items reflects the museum's impressive permanent collections. Subject strengths include American native art; African, Oceanic, Asian, and American art; decorative arts; prints; drawings; photography; contemporary art; and textiles. By appointment, (443) 573-1778.

\section{College and university libraries University System of Maryland}

Baltimore is home to five of the eleven universities within the state's public university system. Libraries and collection highlights include:

Parlett L. Moore Library at Coppin State College (2500 W. North Avenue, www. coppin.edu/library). This library houses the Cab Calloway collection of personal memorabilia from the swing/jazz legend.

Albert S. Cook Library at Towson University (8000 York Road, Towson, cooklibrary.towson.edu/). The library houses the university archives dating from its founding in 1866.

Langsdale Library at the University of Baltimore (1420 Maryland Avenue, langsdale.ubalt.edu/). Included among the more than 70 archival collections are the records of the Baltimore City Department of Planning and those of the Edgar Allan Poe Society.

Health Services and Human Sciences Library at the University of MarylandBaltimore (601 West Lombard, www.umaryland.edu/library/). Established in 1813, this is the first library founded by a medical school in the United States. Other libraries serving the six professional schools and graduate school on this campus include the Thurgood Marshall Law Library and two learning media centers.

Albin O. Kuhn Library and Gallery, University of Maryland-Baltimore County (1000 Hilltop Circle, www.umbc.edu/aok). Special collections include nearly 2 million images documenting the development of pho- 
tography from daguerreotypes to digital imaging, and an extensive research guide on African American photographers. The gallery features works from the library's collections as well as art and artifacts from around the world.

\section{Jobns Hopkins University Libraries}

The Sheridan Libraries encompass the Milton S. Eisenhower Library and its collections at the Albert D. Hutzler Reading Room, the John Work Garrett Library at Evergreen House, and the George Peabody Library, described previously in the section on Mt. Vernon Cultural District libraries.

Named for the eighth president of Johns Hopkins, the Eisenhower Library (3400 North Charles Street) is the university's main research library. Noteworthy special collections include medieval and renaissance manuscripts, German and French literature, and classics in economic history from the 16th to the 20th centuries.

The Albert D. Hutzler Reading Room in Gilman Hall served as the reading room for the university's first library on the Homewood Campus. Encircling the room are 19 handsome stained glass windows depicting early printers.

The John Work Garrett Library at Evergreen House (4545 North Charles Street) houses 8,000 rare books, including some of the most important and beautiful ornithological works of Audubon and Gould, architectural history, 16th- and 17th-century English history and literature, and early Bibles. The entire library collection of 30,000 volumes is housed throughout the Italianate country estate, one of Hopkins' house museums. By appointment, (410) 516-8662.

Additional Hopkins libraries in Baltimore include the Welch Medical Library (1900 East Monument Street), which serves the Medical Institutions campus and offers several service locations or "touchdown suites" throughout the medical school and hospital. The Institute of the History of Medicine collection contains some of the earliest printed editions of the works of classical and medieval medical writers.
Goucher College, Julia Rogers Library (1021 Dulaney Valley Road, www.goucher. edu/library). Founded in 1885, Goucher is a private co-educational liberal arts and sciences college located just eight miles from downtown Baltimore. The Julia Rogers Library boasts several noteworthy special collections. Highlights of the Jane Austen Collection include three extant American copies of Emma, published in 1816 in Philadelphia and the first English edition of Sense and Sensibility, Austen's first book in print published in 1811.

The James Wilson Bright collection on the history of the English language and literature is a particularly significant resource, and the 5,000-volume collection includes many of Goucher's rarest works.

The H. L. and Sara Haardt Mencken Collection includes correspondence between Mencken and his wife, Sara, a 1920 Goucher alumna, as well as books by and about one of Baltimore's most famous writers and social critics.

A unique compilation on the subject of women's lives during war time can be found in the Passano Collection on Women of the South During the Civil War.

Loyola/Notre Dame Library (200 Winston Avenue, www.loyola.edu/library/). Serving the College of Notre Dame of Maryland and Loyola College, this library has the distinction of being one of the first in the country to be owned jointly by two independent colleges. Highlights of the library's special collections include the Gerard Manley Hopkins Collection and the Marion \& Henry J. Knott Fore-edge Painting Collection, which consists of books decorated with watercolor paintings on the page edges.

Baltimore International College, George A. Piendak Library, Commerce Exchange (17 Commerce Street www.bic. edu/). Baltimore's independent college offering specialized degrees in culinary arts and hospitality management is located just two blocks from the Inner Harbor. The library's growing collection features more than 16,000 volumes and more than 120 journals. For a 
particularly delectable treat, visit the Sheldon H. Knorr Gallery for Contemporary and Edible Art, located above the library, which showcases the art created by students, alumni, faculty, and staff.

Baltimore Hebrew University (Joseph Meyerhoff Library, 5800 Park Heights Ave. Baltimore, www.bhu.edu/joseph.html). Baltimore Hebrew University's specialized academic library of Jewish studies includes extensive holdings in Jewish history, philosophy, art, law, and rabbinics. Among the rare book holdings in biblical studies is a volume of the first edition of the Biblia Rabbinica, also known as the Bomberg Bible of 1517, which established the format of the Bible that is still used today. Access to the rare book collection is by appointment only, (410) 578-6936.

\section{African American collections}

Just prior to the Civil War, Baltimore had the highest population of free blacks in the country, although Maryland was a slave state. The free black population built churches, developed educational institutions, and established fraternal organization, and the legacy of this rich African American history is captured in special collections and archives throughout the city, several of which are highlighted below.

Reginald F. Lewis Museum of African American History and Culture Resource Center (830 E. Pratt St., www. africanamericanculture.org). The Resource Center is the largest African American Museum on the East Coast and serves as a repository for books, papers, oral histories, and educational resources on the African American experience in Maryland. It is developing a growing library of reference materials on the history of African Americans.

Morgan State University, Morris A. Soper Library (1700 E. Cold Spring Lane (library.morgan.edu/). The Soper Library serves Maryland's historically black public university and was designated the state's Public Urban University in 1988. Special collections include African American materials that chronicle the achievements and contributions of African Americans throughout the diaspora. A new library is currently under construction and slated for completion by spring 2007.

Sojourner-Douglass College (200 North Center Street, Walter P. Carter Library, www. sdc.edu/resources.htm). Founded in 1972, Sojourner-Douglass is the only private, predominantly African American institution of higher learning in the state of Maryland.

Our Lady of Mount Providence Convent (701 Gun Road, Archives and Special Collections Library, oblatesisters.com/page19. html). Founded in 1829 by Elizabeth Lange (later Mother Mary Lange) and Father James Joubert, the Oblate Sisters of Providence is the first order of Roman Catholic women of color in the world. Highlights of the library collection housed at the convent include manuscripts and photographs, 600 rare books dating from the 1600s to the 1840s; various African American Catholic periodicals and newspapers, and numerous artifacts, including a substantial collection of needlework samplers that were produced by students at St. Frances Academy in the 19th century. By appointment, (410) 242-8500 x135.

The Center for Educational Resources at the Johns Hopkins' Sheridan Libraries (www.cer.jhu.edu) has conducted a preliminary survey of archival and manuscript collections to determine the relevancy of these holdings and further the study of the history of African Americans in Baltimore and the surrounding area. To date, eleven collections have been surveyed and initial findings are being compiled.

If you do have time for an excursion to nearby Annapolis, consider visiting the Nimitz Library at the U. S. Naval Academy (www. usna.edu/Library/), which includes among its special collections the manuscripts of British historical novelist and journalist C. S. Forester, creator of British naval officer Horatio Hornblower. At the Maryland State Archives (www.mdarchives.state.md.us/) holdings range from records dating from the founding of the colony in 1634 to photographs, maps, and decorative and fine arts. $\pi$ 